\title{
The influence of ornithogenic products on the nutrient status of soils surrounding nests on nunataks in Dronning Maud Land, Antarctica
}

\author{
MARTIN P. COCKS. JEAN M. HARRIS, WILLIAM K. STEELE and DAVE A. BALFOUR
}

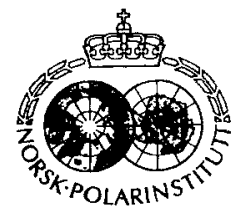

Cocks, M. P., Harris, J. M.. Steele. W. K. \& Balfour, D. A. 1999: The influence of ornithogenic products on the nutrient status of soils surrounding nests in nunataks in Dronning Maud Land, Antarctica. Polar Research $18(1), 19-26$.

The nutrient status of soils surrounding ten snow petrel Pagodroma nivea nests was investigated by sampling along four transects (one up-slope and three down-slope) from each nest. The highest levels for total $\mathrm{N}$ and $\mathrm{P}, \% \mathrm{C}$, nitrite and ammonia (but not nitrate) were associated with the nest itself. Elevated levels of all nutrients still occurred at $1 \mathrm{~m}$ from the nest but dropped to levels similar to those of non-bird influenced soils at $2 \mathrm{~m}$ or $5 \mathrm{~m}$ from the nest. Highest bacterial and algal numbers were also associated with the nest. An experiment to examine the breakdown of guano showed nitrification levels to be insignificant and nutrient release levels very slow.

M. P. Cocks, Botany Department, University of the Westem Cape, Private Bag XI7, Bellville. 7535, South Africa; J. M. Harris, W. K. Steele and D. A. Balfour, Percy FitzPatrick Institute for African Ornithology. University of Cape Town, Private Bag, Rondebosch, 7700, South Africa.

\section{Introduction}

The ice-free mountains or nunataks of Antarctica are isolated from each other and from the ocean by the large tracts of sterile ice that cover most of the continent. The simple ecosystems which occur on these nunataks may be regarded as some of the most isolated ecosystems on earth. A few of these nunataks are used as breeding grounds by various species of sea birds such as Antarctic petrels Thalassoica antarctica, snow petrels Pagodroma nivea and south polar skuas Catharacta maccormicki. The birds are an important vector of nutrients between the ocean and the nunatak ecosystems because of the ornithogenic products (guano, feathers, carcasses and eggshells) they leave behind. Over the past 60 years the view has arisen that birds are a major source of nutrients for the plants of the ecosystems where they breed (R. Smith 1985). This is based on various reports of increased plant abundance on nunataks with bird colonies (Borwa et al. 1966). South African biological research in Antarctica over the past ten years has sought to establish whether there is a direct causal relationship between ornithogenic products and increased floral and faunal diversity and abundance. Published studies to this effect include Ryan et al. (1989), Ryan \& Watkins (1989) and Harris \& Tibbles (1996). All were conducted at the Robertskollen group of nunataks in Dronning Maud Land.

Although several studies have been conducted on the nature and nutrient content of the ornithogenic soils in penguin rookeries at coastal Antarctic sites (Ugolini 1972; Speir \& Cowling 1984; Heine \& Speir 1989), only a few have investigated the soils at petrel colonies on inland nunataks. At Robertskollen, Ryan \& Watkins (1989) found major nutrients $\mathrm{N}, \mathrm{P}$ and $\mathrm{K}$ to be significantly higher near the snow petrel colony. Since this study, several others have investigated the biota, nutrient levels and origins of nutrients (using ${ }^{15} \mathrm{~N}$ isotopes) in various microhabitat-types at Robertskollen (See Harris \& Tibbles 1996; Cocks, Balfour et al. 1998; Cocks, Newton et al. 1998).

Snow petrels breed in sheltered crevices (Ryan \& Watkins 1989), unlike Adelie penguins and Antarctica petrels (Mehlum et al. 1988) which choose open nesting sites. Thus snow petrel nests are spaced further apart within the colony. There should therefore be a greater variation in the spread of nutrients around each nest, with the nests themselves being hot spots for high nutrient levels and possibly also micro-organism numbers. In this study we investigated the spatial distribution of nutrients around snow petrel nests. Soil bacterial and algal numbers were quantified and related to 
nutrient levels at various distances from nests. We also measured soil nitrification rates in nests to gain a better understanding of the nutrient dynamics at the site and whether these concur with the findings of previous studies at Robertskollen.

\section{Study site and methods}

The study was conducted at Robertskollen, a group of geologically similar nunataks in the northern Ahlmannryggen, Dronning Maud Land. Biota native to Robertskollen are described by Ryan et al. (1989), who also described the locations of the unofficially named nunataks mentioned in this study. About 600 pairs of snow petrels breed on the nunataks at Robertskollen (Steele \& Newton 1995), 250 of these on the nunatak Ice Axe Peak, where ten nests were chosen for this study. Four transects were laid out with the nest as the starting point of each. One transect went up-slope from the nest, another went directly down-slope from the nest, and two others at $15^{\prime \prime}$ angles on either side of the down-slope transect, thus giving transects at these circle positions: $0^{\circ}$ (up-slope) and $165^{\circ}, 180$ and $195^{\circ}$ (down-slope) (Fig. 1). Soil samples were collected in the nest itself and at $1 \mathrm{~m}, 2 \mathrm{~m}$ and $5 \mathrm{~m}$ intervals along the four transects (Fig. 1). The soil

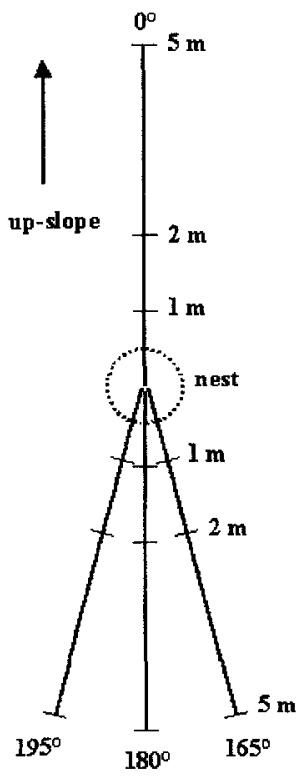

Fig. 1. Orientation of the four sampling sites around each nest. samples collected at each site were used to determine: (1) total nitrogen, phosphorus and carbon levels (collected in small paper bags and dried); (2) nitrate, nitrite and ammonium (collected as $2 \mathrm{M} \mathrm{KCl}$ extracts) and (3) soil algal and bacterial counts (collected in small sterile plastic vials).

Total nitrogen levels were determined by microKjeldahl digests using selenium digest tablets followed by colorimetric determination of the ammonia content (Bremner \& Mulvaney 1982). A nitric, sulfuric and perchloric acid digestion (Grimshaw 1985) followed by colorimetric determination of the phosphate content (Murphy \& Riley 1962) was used to determine the total phosphorus levels of the samples. The dichromate oxidation method (Walkley \& Black 1934) was used for the determination of total percentage carbon. The methods described by Stock (1983) were used for the determination of nitrate (coppercadmium), nitrite (Griess-Ilosvay) and ammonium (indo-phenol blue) from the $2 \mathrm{M} \mathrm{KCl}$ solutions collected in the field (these were kept frozen until analysis when they were diluted two-fold).

The enumeration of soil bacteria was carried out using $1 \mathrm{~g}$ samples which were diluted in $0.01 \mathrm{M}$ tetrasodium pyrophosphate and stained with DAPI (4'6-diamine-2-phenylindole, $5 \mu \mathrm{g} \cdot \mathrm{ml}^{-1}$ ) (Porter \& Feig 1980) for 20 minutes (Schallenberger et al. 1989) after being sonicated for five minutes at $45-50 \mathrm{~Hz}$ (Ellery \& Schleyer 1984; Velij \& Albright 1986). They were then filtered onto prestained (Irgalon Black) $0.2 \mu \mathrm{m}$ nucleopore polycarbonate filters and counted at 1000 magnification with a mercury light source, Nikon Neofluar 100/1.30 oil objective and Nikon DM400 filter block. Soil algae were counted using a light microscope with a grid objective at 1000 magnification.

The breakdown of guano deposited in the nests was investigated to elucidate nutrient turnover rates in the ecosystem. Soil and guano collected in ten nests were combined, ground with a mortar and pestle and divided into five replicates. Each replicate was divided in two to give a $15 \mathrm{~g}$ experimental sample and a $15 \mathrm{~g}$ control sample. The samples were placed in sterile glass jars. $\mathrm{N}$ Serve $(63 \mu \mathrm{l})$ and distilled water $(100 \mathrm{ml})$ were added to each of the control samples to inhibit nitrification. A $1 \mathrm{ml}$ sample was removed and added to a $2 \mathrm{M} \mathrm{KCl}$ solution for the nitrate, nitrite and ammonium analyses. The samples were placed in a sheltered spot outside where they 
The influence of ornithogenic products on the nutrient status of soils 21
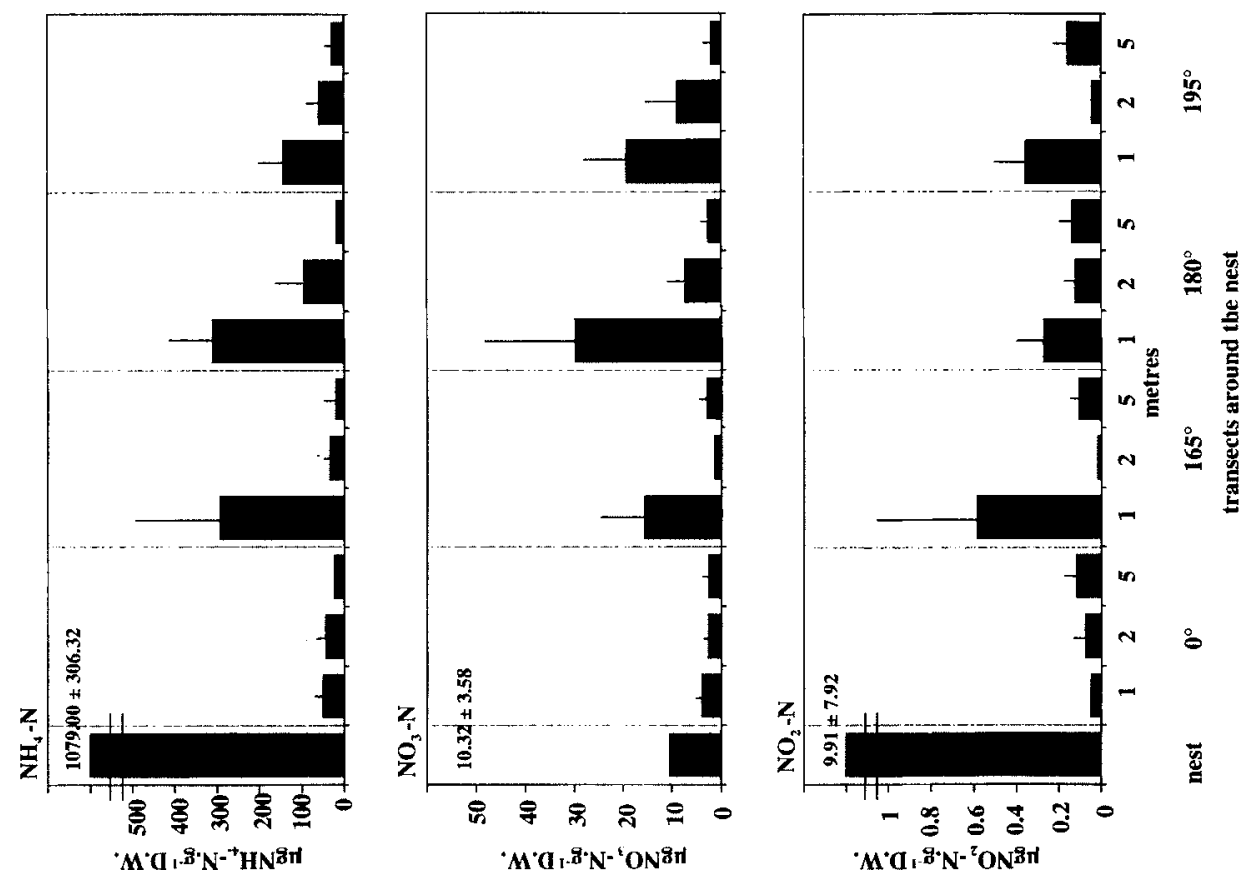

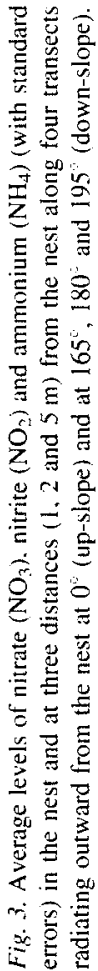
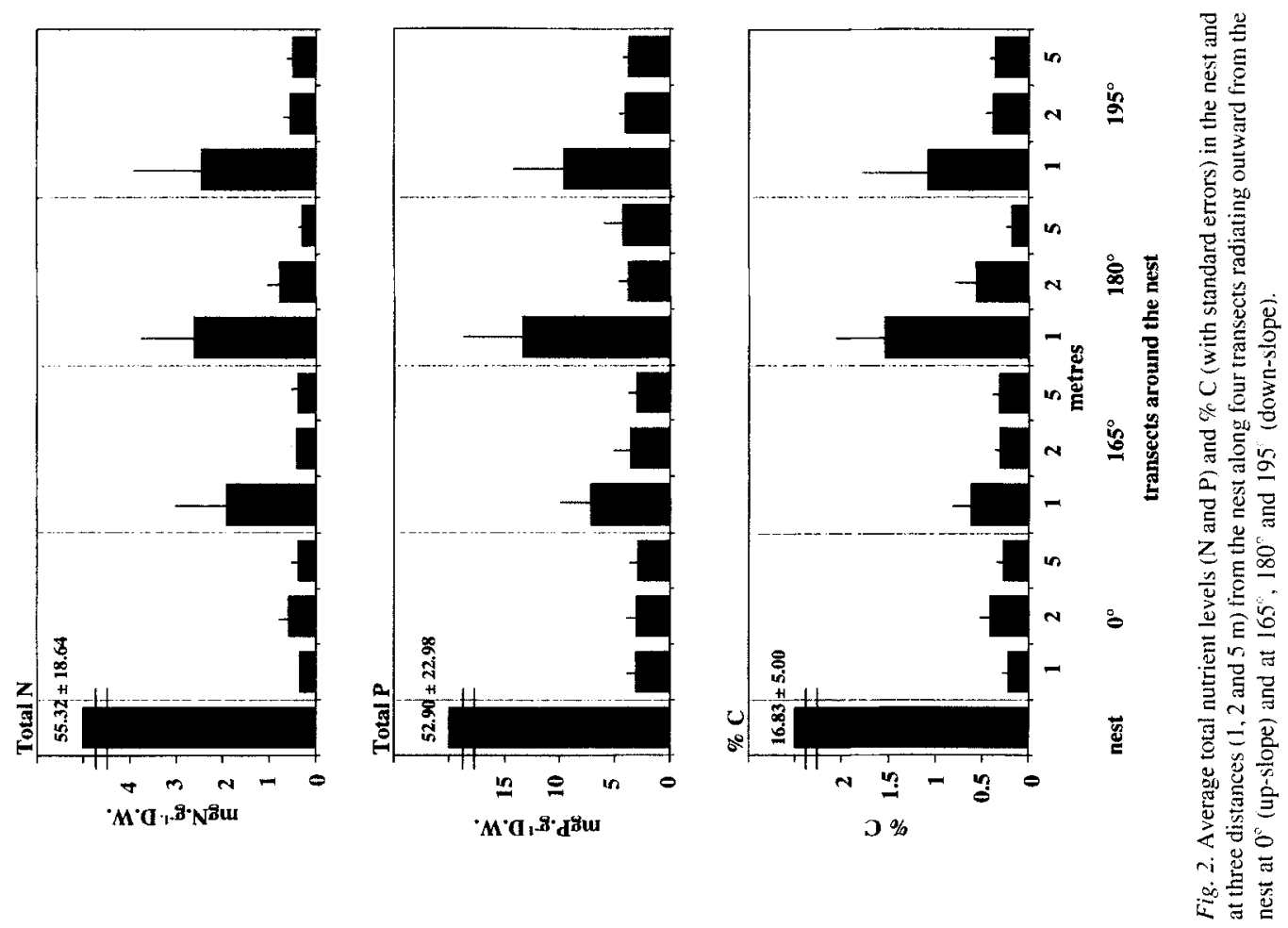
experienced ambient temperature conditions; further $1 \mathrm{ml}$ samples were taken every five days over the next 20 days. The samples were aerated continually during the duration of the experiment to prevent them from turning anaerobic.

\section{Results}

The total nutrient levels ( $\mathrm{N}, \mathrm{P}$ and $\mathrm{C}$ ) should be viewed as long-term assessments as they are less likely to change quickly, while those of ammonium, nitrate and nitrite fluctuate more rapidly and represent a snap-shot of conditions at the time of study. In the nests the levels of the total nutrients (N, P and C) (Fig. 2) far exceeded those for any of the positions along the four transects around the nests. The same was true for ammonium and nitrite levels (Fig. 3), but levels of nitrite were an order of magnitude below those for nitrate or ammonium and were highly variable (high standard error). Nitrate levels, however, were highest at $1 \mathrm{~m}$ from the nest along the $180^{\circ}$ transect (i.e. down-slope).
Both measures of biological activity, i.e. the numbers of soil algae and bacteria, were highest in the nests (Fig. 4). Nest algae numbers were far in excess of those at other positions along the transects around the nests. In the case of bacteria numbers, the difference between the nests and non-nest positions was not as great as with the algae.

When the data were grouped according to distance from the nest (Table 1), levels for all the soil nutrients were significantly higher at $1 \mathrm{~m}$ from the nest than at $2 \mathrm{~m}$ or $5 \mathrm{~m}$. However, when the data were grouped according to orientation around the nest, there were no significant differences (except for \% C) (Table 1). Beyond the nests themselves, neither bacterial nor algal numbers showed any significant differences with distance from the nest or orientation relative to it (Table 1). There was very little variation in the levels of nutrients at the $1 \mathrm{~m}, 2 \mathrm{~m}$ or $5 \mathrm{~m}$ distances from the nest along the $0^{\circ}$ transect (Figs. 1, 2); average levels were lower at $1 \mathrm{~m}$ on this transect in comparison to the other three transects at $1 \mathrm{~m}$ but these differences were not statistically significant
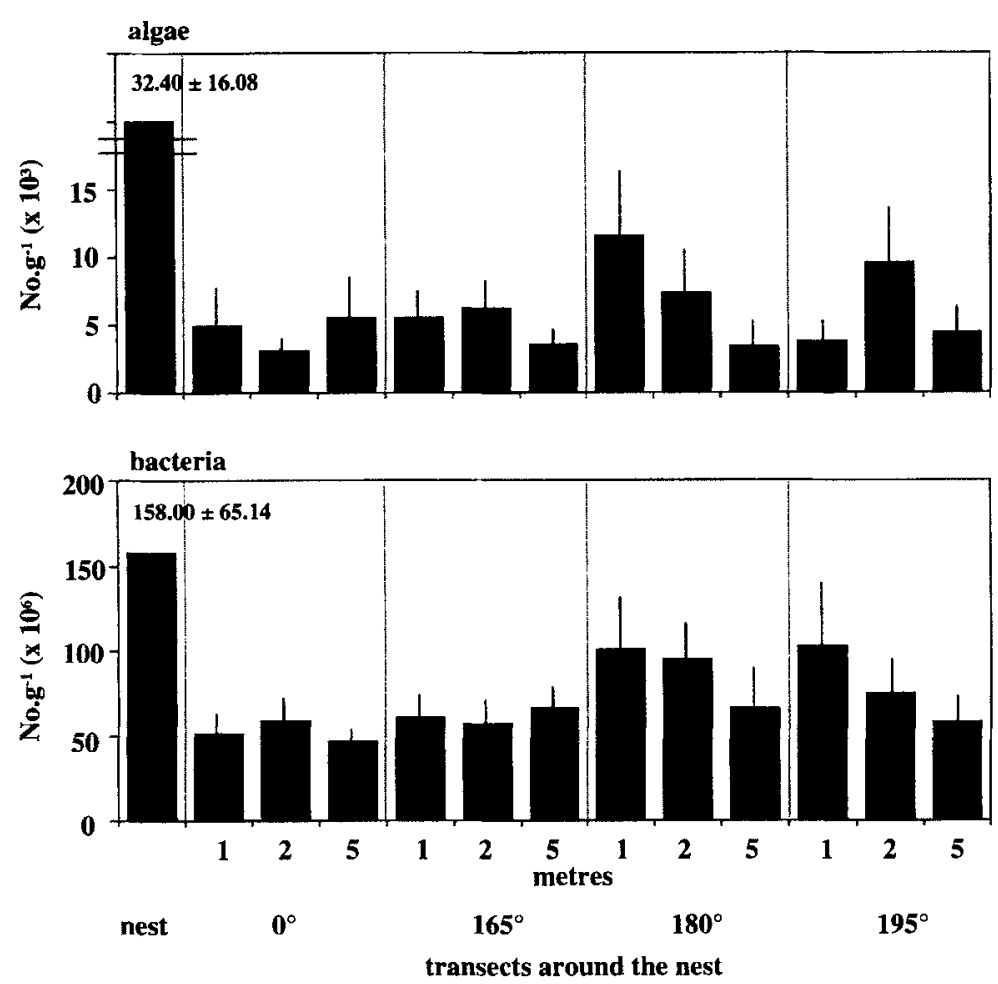

Fig. 4. Average numbers of soil bacteria and soil algae (with standard errors) in the nest and at three distances $(1,2$ and $5 \mathrm{~m})$ from the nest along four transects radiating outward from the nest at $0^{\circ}$ (up-slope) and at $165^{\circ}, 180^{\circ}$ and $195^{\circ}$ (down-slope). 
Table 1. The results of a two-way ANOVA of average (log normalized) long-term (total $\mathrm{N}, \mathrm{P}$ and $\mathrm{C}$ ), short-term $\left(\mathrm{NH}_{4}, \mathrm{NO}_{3}, \mathrm{NO}_{2}\right)$ and biological (total numbers of bacteria and algae) soil factors with orientation of the transect vis-à-vis the nest and the distance from the nest (see Figs. 1, 2, 3). Different letters (a or b) denote significant differences between sites using LSD test ( $p<0.05$ ).

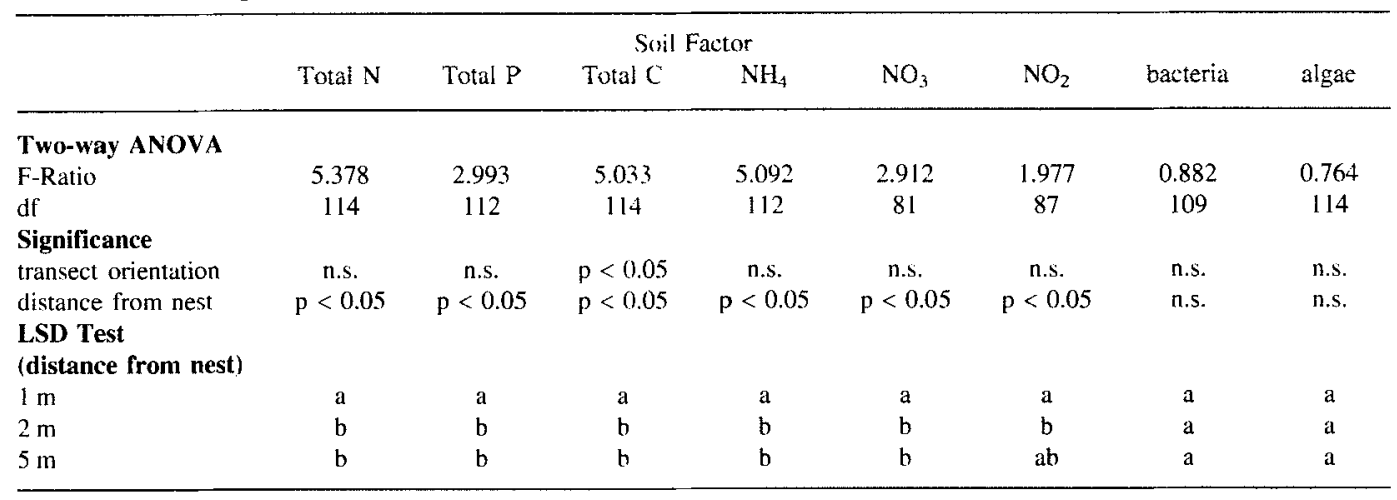

Table 2. The results of a one-way ANOVA of average (log normalized) long-term (total N, P and C), short-term $\left(\mathrm{NH}_{4}, \mathrm{NO}_{3}, \mathrm{NO}_{2}\right.$ ) and biological (total numbers of bacteria and algae) soil fuctors with orientation of the transect vis-à-vis the nest at $1 \mathrm{~m}$ from the nest (see Figs. I, 2, 3).

\begin{tabular}{lcccccccc}
\hline & \multicolumn{9}{c}{ Soil Factor } \\
& Total $\mathrm{N}$ & Total $\mathrm{P}$ & Total $\mathrm{C}^{\circ}$ & $\mathrm{NH}_{4}$ & $\mathrm{NO}_{3}$ & $\mathrm{NO}_{2}$ & bacteria & algae \\
\hline $\begin{array}{l}\text { One-way ANOVA } \\
\text { F-Ratio }\end{array}$ & 2.132 & 1.522 & 3.170 & 2.460 & 1.030 & 1.239 & 0.382 & 0.273 \\
df & 36 & 35 & 35 & 35 & 30 & 30 & 34 & 35 \\
Significance & n.s. & n.s. & $\mathrm{p}<0.05$ & n.s. & n.s. & n.s. & n.s. & n.s. \\
\hline
\end{tabular}

(except for \% C) (Table 2). This was due to the high standard deviation associated with the nutrients of the three positions below the nest $\left(165^{\circ}, 180^{\circ}\right.$ and $\left.195^{\circ}\right)$ at one $1 \mathrm{~m}$ (Figs. 2, 3).
The results of the experiment to observe the breakdown of guano from the nests showed little change in the average levels of nitrate over the 20 days during which the experiment was run (Fig. 5).
Fig. 5. Average levels of nitrate $\left(\mathrm{NO}_{3}\right)$ and ammonium $\left(\mathrm{NH}_{4}\right)$ in solutions of guano from snow petrel nests measured over 20 days, $\Delta=\mathrm{NO}_{3}: \bullet=\mathrm{NH}_{4}$. Solid line = experiment; dotted line $=$ control $($ standard errors too small to indicate).

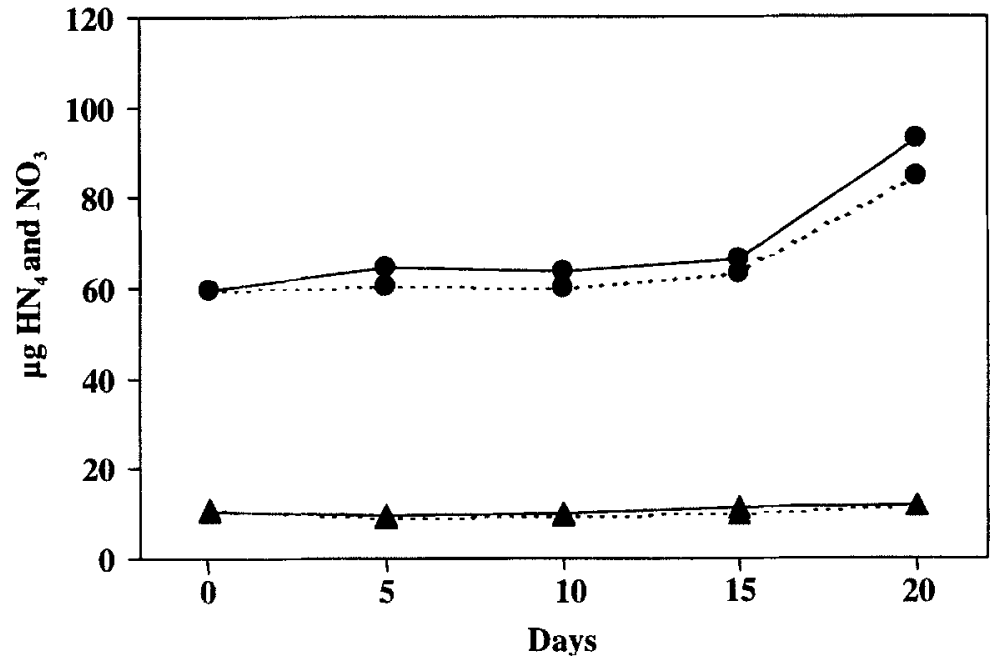


Ammonium levels increased both in the experimental samples and the control, especially over the last five days of measurement.

\section{Discussion}

In this study, the average levels of all nutrients (except nitrate) were highest in the nest. In Adelie penguin Prygocelis adeliae rookeries at Cape Bird, levels of 139 to $164 \mathrm{mg} \mathrm{N} . \mathrm{g}^{-1}, 29$ to $35 \mathrm{mg} \mathrm{P.g} \mathrm{g}^{-1}$ and 21 to $24 \% \mathrm{C}$ were obtained by Speir \& Cowling (1984), and Ugolini (1972) measured $116 \mathrm{mg} \mathrm{N}^{-1}, 63 \mathrm{mg} \mathrm{P.g}{ }^{-1}$ and $21.8 \%$ $\mathrm{C}$ at Cape Royds. Total $\mathrm{N}$ levels recorded in this study were below half of those recorded at these other sites. Total P levels were similar and \% C was lower than levels recorded at these sites. Ammonium levels in the nest of our study were far below those recorded for Cape Bird soils (41200 to $41700 \mu \mathrm{g} \cdot \mathrm{g}^{-1}$ ) (Speir \& Cowling 1984), but $\mathrm{NO}_{3^{-}}$ $\mathrm{N}$ and $\mathrm{NO}_{2}-\mathrm{N}$ levels were of the same order of magnitude (67 to $72 \mu \mathrm{g} \cdot \mathrm{g}^{-1}$ and 4 to $5 \mu \mathrm{g} \cdot \mathrm{g}^{-1}$ respectively). Ryan et al. (1989), working at Robertskollen, found lower levels for total $\mathrm{N}$ (14 mg.g $\left.\mathrm{g}^{-1}\right)$ and total P (6.06 mg.g $\mathrm{g}^{-1}$ but similar levels for \% C (22.9\%) compared to the nest levels in our study, but their values are derived from only one nest. A subsequent study by Cocks, Newton et al. (1998) examined nutrient levels within a $1 \mathrm{~m}$ radius of occupied nests $(n=15)$ (whereas in the study reported here, samples were also taken from inside the nest) and found levels more akin to those at $1 \mathrm{~m}$ from the nest in the present study for total $P$ ( $10 \mathrm{mg} \cdot \mathrm{g}^{-1}$ ), total $\mathrm{N}\left(30 \mathrm{mg} \cdot \mathrm{g}^{-1}\right.$ ) and ammonium $\left(300 \mu \mathrm{g} \cdot \mathrm{g}^{-1}\right)$. Nitrate levels $\left(100 \mu \mathrm{g} \cdot \mathrm{g}^{-1}\right)$, however, were higher in the study of Cocks, Newton et al. (1998) than either in the nest or at $1 \mathrm{~m}$ in the present study. Thus, at Robertskollen the highest levels of nutrients are confined to the immediate vicinity of nests, and there was little lateral movement of the nutrients.

There was a considerable drop in average levels of all nutrients (except nitrate) at $1 \mathrm{~m}$ from the nest. Although there were no significant differences in the average levels on the four transects at this distance (except for \% C), the average levels were consistently lower along the $0^{\circ}$ transect and associated with low standard errors. It therefore appears that nutrients are preferentially transported downhill from the nest but the high variability in the average levels in the three transects below the nest indicates that transport of the nutrients downhill from the nest is sitespecific, depending on the amount of runoff through the area of the nest. The higher levels of nitrate at $1 \mathrm{~m}$ from the nest may reflect more favourable conditions for nitrification than within the nest itself.

At $2 \mathrm{~m}$ or $5 \mathrm{~m}$ from the nests levels of all the nutrients were reduced even further and were within the range for nutrients in non-bird influenced soils, e.g. soil from Wilke's Land, 0.1 to $2.4 \mathrm{mg} \mathrm{N} . \mathrm{g}^{-1}$ and 0.4 to $2.2 \mathrm{mg} \mathrm{P.g}{ }^{-1}$ (Heatwole et al. 1989), and Robertskollen, $1.6 \mathrm{mg} \mathrm{N} . \mathrm{g}^{-1}$ and $0.18 \mathrm{mg} \cdot \mathrm{g}^{-1}$ (Ryan et al. 1989). In their study at Robertskollen, Cocks, Newton et al. (1998) found that the soil from open polygons at least $5 \mathrm{~m}$ from the nest did not have significantly higher levels of total nitrogen, nitrate or ammonium than similar sites on a nunatak which had no nesting birds. However, soils from under moss turfs on the nunatak with nesting birds had significantly elevated levels of total nitrogen, phosphorus and nitrate, but not ammonium, and appear to act as a sink for bird-derived nutrients. This was confirmed by ${ }^{15} \mathrm{~N}$ stable isotope analysis, which revealed a strong bird signal for all sites on the nunatak with breeding birds (Cocks, Balfour et al. 1998). Thus, although there was a considerable drop in nutrient levels between the nest and more distant areas, the nutrients are still of bird origin.

The highest numbers of soil bacteria in the nests concur well with the studies of previous findings at Robertskollen. Harris \& Tibbles (1996) found that out of the four microhabitat types they examined, the highest heterotrophic soil bacteria productivity levels were associated with nests. Cocks, Newton et al. (1998) associated this habitat with the highest $\mathrm{CO}_{2}$ flux in the five microhabitat types they examined. In both of these studies levels of heterotrophic soil productivity and $\mathrm{CO}_{2}$ flux in the soil from open polygons (at least $5 \mathrm{~m}$ away from nests) were considerably lower while those from under mosses were intermediate. Both studies attributed the higher levels of the nest soils to the more favourable temperature. moisture and nutrients in this microhabitat. Various other studies in Antarctica have also found higher bacterial numbers associated with moist, mosscovered soils (Bailey \& Wynn-Williams 1982; Smith \& Tearle 1985) and high nutrient containing ornithogenic soils (Ramsay 1983; Ramsay \& Stannard 1986; Line 1988; Roser et al. 1993). It 
is difticult, at Robertskollen, to ascertain which of these factors is most important in the nest soils, but it is clear that nests represent the most favourable combinations of these factors for bacterial growth whereas open polygon soils are the least favourable combination. Thus, the lower bacterial numbers on transects beyond the nests represent less favourable moisture, temperature and nutrient conditions. The slightly more favourable nutrient conditions below the nests did not appear to influence the bacterial numbers, however. The variability of the data along the transect suggest that some of the samples were collected from sites that happened to fall into microhabitats more favourable for bacterial production (probably more sheltered). Unfortunately, no moisture or temperature data were collected to confirm this. Higher levels of soil algae have been associated with moist. nutrient-rich sites around petrel colonies in Antarctica with foliose Prasiola crispa being prominent (Broady 1987. 1989). This alga is also common at moist sites near nests at Robertskollen (Ryan et al. 1989) and would contribute to the higher counts of soil algae near nests.

The guano nitrification experiment helped to confirm that even within the snow petrel colony nutrient turnover rates are very low. Similarly low levels of nitrification have been recorded for other sea bird colonies at high latitude such as macaroni penguin Eudyptes chrysolophus colonies on Marion Island (Lindeboom 1984). Volatilization of the high resulting levels of ammonia in the nest raises the ${ }^{15} \mathrm{~N} /{ }^{14} \mathrm{~N}$ ratio since the lighter isotope is lost during this process (Mizutani et al. 1985). This results in characteristically high ${ }^{15} \mathrm{~N} /{ }^{14} \mathrm{~N}$ ratios which have been measured at Robertskollen (Cocks, Balfour et al. 1998) and other seabird colonies (Mizutani \& Wada 1988).

In conclusion. the snow petrel nests at Robertskollen apparently represent hot spots for nutrients and soil bacteria and algae. The nutrient levels drop off rapidly with distance from the nest such that at $2 \mathrm{~m}$ from the nest they reach the levels found outside the colony.

Acknowledgements. - The Antarctic Division of the South African Department of Environmental Affairs and Tourism funded this study. We would also like to thank Ian Newton for his help with the analysis of the samples and Trevor Probyn and Willy Stock for their helpful advice.

\section{References}

Bailey, A. D. \& Wynt-Williams, D. D. 1982: Soil microbiological studies at Signy Island, South Orkney Islands. $B r$. Antart. Surt: Bull. 51, 167-191.

Borwa, G. T., Holdgate, M. W. \& Tilbrook, P. J. 1966: Biological investigations in Tattanfjella and central Heimefrontfjella. Br. Amart. Surt. Bull. 9, 63-70.

Broady. P. A. 1987: A floristic survey of algae at four locations in northern Victoria Land. New Zealand Antartic Record 7 , $8-19$.

Broady. P. A. 1989: Survey of algae and other terrestrial biota at Edward VII peninsula, Marie Byrd Land. Antarctic Science I, 215-224.

Bremner, J. M. \& Mulvaney, C. S. 1982: Nitrogen - total. Pp. 595-622. In Page, A. L. (ed.): Methods of soil analysis. Part 2: Chemical and microbiological properties, Pp. 595-622. Madison, Wisconsin: Am. Soc. Agron.

Cocks, M. P., Balfour, D. A. \& Stock, W. D. 1998: On the uptike of ornithogenic products by plants on the inland mountains of Dronning Maud Land. Antarctica, using stable isotopes. Polar Biol. 20, 107-111.

Cocks. M. P., Newton, I. P. \& Stock, W. D. 1998: Bird effects on ornithogenic processes in soils from five microhabitats on a nunatak with and without breeding snow petrels in Dronning Maud Land, Antarctica. Prilar Biol. 20, 112-120.

Ellery, W. N. \& Schleyer, M. H. 1984: Comparison of homogenization and ulirasonification as techniques in extracting attached sedimentary hacteria. Mar. Ecol. Prog. Ser. 15. 247-250.

Grimshaw, H. M. 1985: The determination of total phosphorus in soil by acid digestion. In Prowland. A. P. (ed.): Chemical andixis in enironnentil tesearch, ITE ssmposium no 18 . Pp. 92-95. London: Institute for Terrestrial Ecology/National Environment Research Council.

Harris, J. M. \& Tibbles, B. J. 1996: Nest and moss beds: sites of enhanced soil bacterial productivity on isolated inland nunataks of continental Antarctica. Microb. Ecol. 3.3, $106-123$

Heatwole, H., Saenger, P., Spain, A.. Kerry, E. \& Donelan, J. 1989: Biotic and chemical characteristics of some soils from Wilke's Land, Antarctica. Antarctic Science 1, 225-234.

Heine, J. C. \& Speir. T. W. 1989: Ornithogenic soils of the Cape Bird Adelie penguin rookery, Antarctica. Polar Biol. 10. $89-99$.

Lindeboom. H. J. 1984: The nitrogen pathway in a penguin rookery. Ecology 65, 269-277.

Line, M. A. 1988: Microbial flora of some soits of Mawson Base and the Vestfold Hills. Polar Biol. 8, 421-427.

Mehlum. F., Gjessing, Y.. Haftorn, S., Bech, C. 1988: Census of breeding Antarctic petrels Thalassoica antarctica and physical features of the breeding colony at Svarthamaren. Dronning Maud Land, with notes on breeding snow petrels Pagatroma nitera and south polar skua Catiaracta naccormicki. Polar Res. 6, 1-9.

Murphy, J. \& Riley. J. P. 1962: A modified single solution method for the determination of phosphate in natural waters. Analyica Chemica Acta 27. 31-36.

Mizutani, H., Kabaya, Y. \& Wada, E. 1985: Ammonia volatilization and high ${ }^{15} \mathrm{~N} /{ }^{14} \mathrm{~N}$ ratio in a penguin rookery in Antarctica. Geochem. J. 19, 323-327.

Mizutani, H. \& Wada, E. 1988: Nitrogen and carbon isotope ratios in sea bird rookeries and their ecological implications. Ecology 69, 340-349. 
Porter, K. G. \& Feig, Y. S. 1980: The use of DAPI for identifying and counting aquatic microflora. Limnol. Oceanogr. 25, 943-948.

Ramsay, A. J. 1983: Bacterial biomass in ornithogenic soils of Antarctica. Polar Biol. 1, 221-225.

Ramsay, A. J. \& Stannard, R. E. 1986: Number and viability of bacteria in omithogenic soils of Antarctica. Polar Biol. 5, 195-198.

Roser, D. J., Seppelt, R. D. \& Ashbolt, N. 1993: Microbiology of ornithogenic soils from the Windmill Islands, Budd Coast, continental Antarctica: microbial biomass distribution. Soil. Biol. Biochem. 25, 165-175.

Ryan, P. G. \& Watkins, B. P. 1989: Snow petrels breeding biology at an inland site in continental Antarctica. Colon. Waterbirds 12, 176-184.

Ryan, P. G., Watkins, B. P., Dastych, H., Eicker, A., Foissner, W., Heatwole, H., Miller, W. R. \& Thompson, G. 1989: Biological survey of Robertskollen, western Dronning Maud Land: area description and preliminary species lists. S. Afr. J. Antarct. Res. 19. 10-20.

Schallenberger, M., Kalff, J. \& Rasmussen, J. B. 1989: Solutions to problems in enumerating sediment bacteria by direct counts. Appl. Environ. Microbiol. 55, 1214-1219.
Smith, H. G. \& Tearle, P. V. 1985: Aspects of microbial and protozoan abundances in Signy Island Fellfields. Br. Antarct. Surv. Bull. 68, 83-90.

Smith, R. I. L. 1985: Nutrient cycling in relation to biological productivity in Antarctic and Sub-Antarctic terrestrial and freshwater ecosystems. In Siegfried, W. R., Condy, P. R. \& Laws, R. M. (eds.): Antarctic nutrient cycles. Pp. 138-155. Berlin: Springer Verlag.

Speir, T. W. \& Cowling. J. C. 1984: Omithogenic soils of the Cape Bird Adelie penguin rookeries, Antarctica. I: Chemical properties. Polar Biol. 2, 199-205.

Steele, W. K. \& Newton, I. P. 1995: New distributional and breeding records of birds in the Ahlmannryggen, western Dronning Maud Land, Antarctica, 1991-1995. Mar. Orn. 23, 47-52.

Ugolini, F. C. 1972: Ornithogenic soils of Antarctica. Antarctic Research Series 20, 181-189.

Velij, M. I. \& Albright, L. J. 1986: Microscopic enumeration of attached marine bacteria of seawater, marine sediment. faecal matter, and kelp blade samples following pyrophosphate and ultrasound treatments. Can. J. Microbiol. 32, 12!-\$26.

Walkley, A. \& Black, I. A. 1934: An examination of the Degtjareff method for determining soil organic matter and the proposed modification of the chromic acid titration method. Soil. Sci. 37, 29-38. 